UDC 629.135.083.02/.06 (045)

Vitaliy Kralya, assoc. Prof.

Andrey Khimko

Victor Borodiy

Alexander Yakobchuk

\title{
FACILITIES FOR RESTORATION OF MONORAIL OF MECHANIZATION OF A WING OF AIRCRAFTS
}

\author{
NAU Department of Technologies of Restoration of Air Engineering
}

E-mail: witlab@nau.edu.ua

\begin{abstract}
The adaptations on removal of a defective layer and grinding of monorail of extension - retraction of flaps and slats of aircrafts are developed. Their application will allow essentially to lower time spent on restoration of a monorail, and will raise quality of processing of a detail at repair.
\end{abstract}

Розроблено пристосування для видалення дефектного шару $і$ шліфування монорейок випуску-збирання закрилків і передкрилків літаків, застосування яких дозволить знизити час, витрачений на відновлення монорейки, і підвищить якість обробки деталі при ремонті.

\section{Introduction}

The rails of mechanization of a wing concern - to number of the most mass and expensive details of modern passenger and transport airplanes. While in service on racing tracks of rails, in places of a stop of rollers, the zones of elaboration are formed, which depth already before the first repair can exceed the established limiting size of deterioration, in this connection there is a necessity of replacement of a rail.

The replacement of the damaged rails at repair causes the large material input on purchase of spare parts.

The elaboration from contact interaction with rollers of carriages is the basic defect determining the further operational suitability of rails of mechanization of a wing at repair.

The analysis of the locations [1], sizes and character of damages allows to make a conclusion, that the most intensive deterioration of a rail occurs at a take-off position of flap, in time of taxing and revving-up engines.

In these conditions most intensive, apparently, takes place vibrating loading, causing slipping and dynamic interaction of contacting surfaces in interface a rail - roller.

The elaboration is formed in places of the contact appropriate to extreme positions of rollers at retracted and extended positions of flaps and slats.

The research of topography of the damaged surface of monorails shows, that the elaboration is formed as a result of relative cyclic slipping between rollers and working surface of a rail and, to the attributes is classified as fretting [2].

\section{The analysis of researches and publications}

The problem of restoration of monorails of mechanization of a wing of airplanes recently has found distributions in works [1;3-5].
One works $[1 ; 3]$ are devoted to a choice of coatings, others $[4 ; 5]$ at the choice of methods of applying of restored coatings.

So the authors of work [4] applied coatings by plasma, detonation, gas-flame methods. Determined the wear resistance of some coatings applied by various ways. In work [5] the researches on application impulse-plasma evaporation are carried out.

The authors $[1 ; 3]$ investigating a plenty of coatings, analyzed their wear resistant properties and durability of coupling with a basis.

The researches till their fretting resistance are carried out. The comparative characteristics of the majority used in aircraft gas-thermal coatings are received.

These works offer the decision of a problem of a choice of a coating and method of its applying, but the technological aspects on repair of a monorail do not mention. In the given work we develop devices on preparation and polishing of monorails of a wing at its restoration.

\section{Production of a task}

The purpose of our work consists in development of devices by preparation monorails to restoration and polishing after evaporation.

\section{Devices for repair of rails of mechanization of a wing of airplanes}

The devices for removal of a defective layer at repair of rails of mechanization of a wing is submitted in a fig. 1 .

Removal of metal is made under the circuit submitted on a fig. 2 by an abrasive circle of the special form 5 .

The form of a circle is caused by features of a method of restoration. 


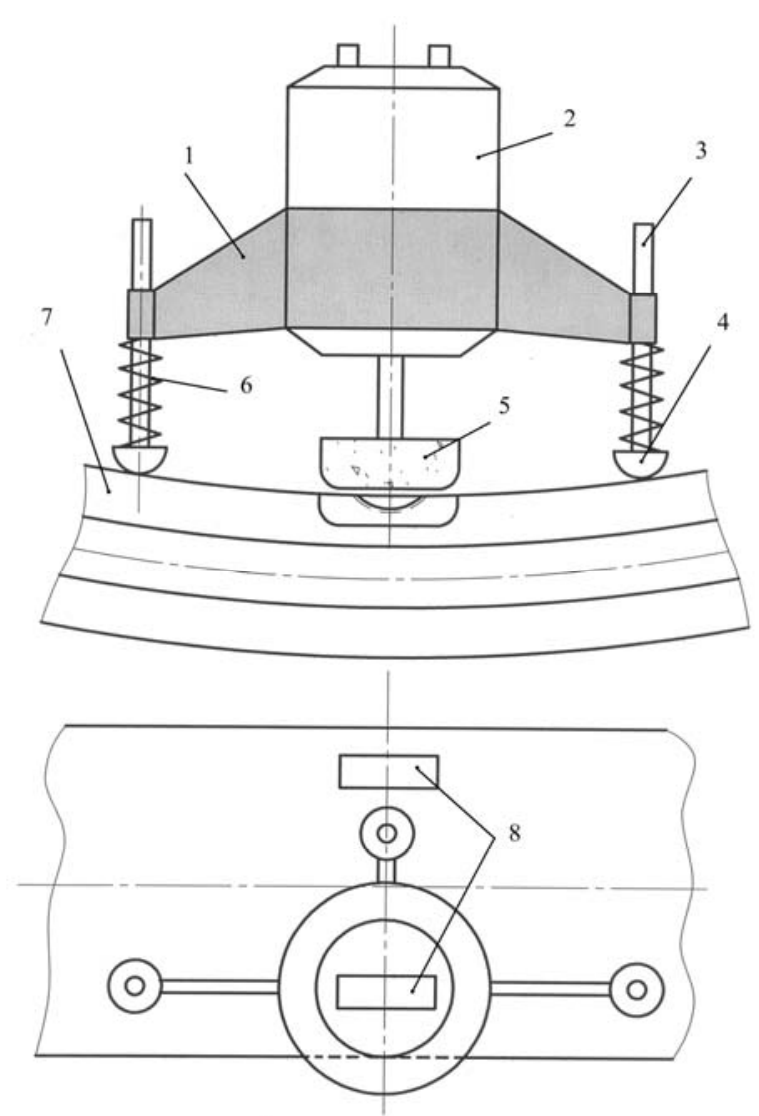

Fig. 1. The circuit of the device for removal of a defective layer at repair of monorails of mechanization of a wing:

1 is device for fastening the pneumatic tool;

2 is pneumatic tool;

3 is guide;

4 is legs-terminators for guides;

5 is abrasive tool;

6 is spring;

7 is monorail;

8 is defects on a monorail owing to operation

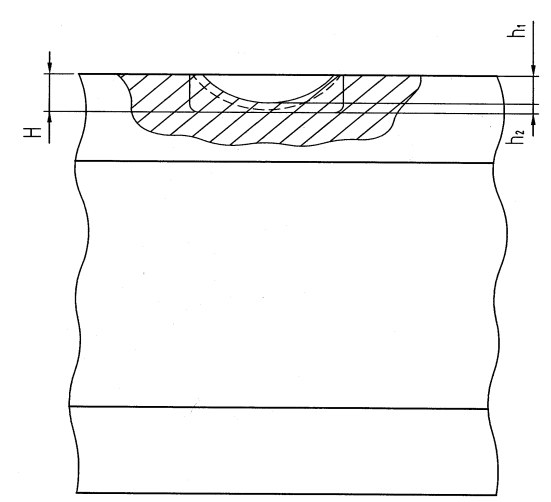

Fig. 2. The circuit of extraction of defective layer at repair of monorails' section of a wing: $H$ is the depth, on which the layer of metal is removed;

$h_{1}$ is the deep of seen defect;

$h_{2}$ is the deep of defective layer
At use of gas-thermal coatings, the removal of the worn out sites of a monorail should occur at a right angle in avoidance peeling of a coating [6], in time of evaporation and grinding.

The device, developed by us, allows to remove a defective layer from a surface of a detail with high accuracy under the formula (fig. 2):

$H=h_{1}+h_{2}$.

The depth $H$, on which the layer of metal is removed, develops of seen defect (wearing) $h_{1}$ of a monorail and defect of a superficial layer $h_{2}$, which size is determined by methods of the not destructive control.

On the pneumatic or electrical tool 2 the special device 1 fastens, with the help of clamps, on which three directions guides are fixed 4 .

They are located so that reliably to keep the working tool on a detail 3 .

On the one hand of guides the legs 4 of a special material protecting the device from displacement on a monorail are located, on the other hand stoppers preventing a start of the guide from eye of the device.

Also on guides there is a marking, where the depth, on which falls abrasive tool is supervised. For convenience of work the adaptation is supported by three springs 6 .

It is necessary to note, that each restored damage is calculated individually: a diameter of the abrasive tool and depth of damage. The device for polishing of restored region of monorails after evaporation is submitted in a fig. 3 .

The device allows to make polishing of rails of mechanization of a wing 3 on given radius.

The pneumatic or electrical tool 1 is kept in the device 2 and on rigidly fixed guides 7 , grinds a restored material 4 level with a surface.

On the guides the freely rotating terminators 5 , made from firm rubber are located.

Their length should exceed the thickness of the abrasive tool 6 on some millimeters on two sides.

Located thus guides and the terminators allow to grind only evaporated covering, not damaging a working surface of a monorail if to warp or to incline the pneumatic tool during work.

Radius, on which the polishing of monorails is made, is exposed with the help of the standards and is periodically controlled during work.

For monorails of various flying vehicles and monorails of various purposes (the extension retraction of the flaps, slats) is necessary to adjust various radius on the adaptation. 

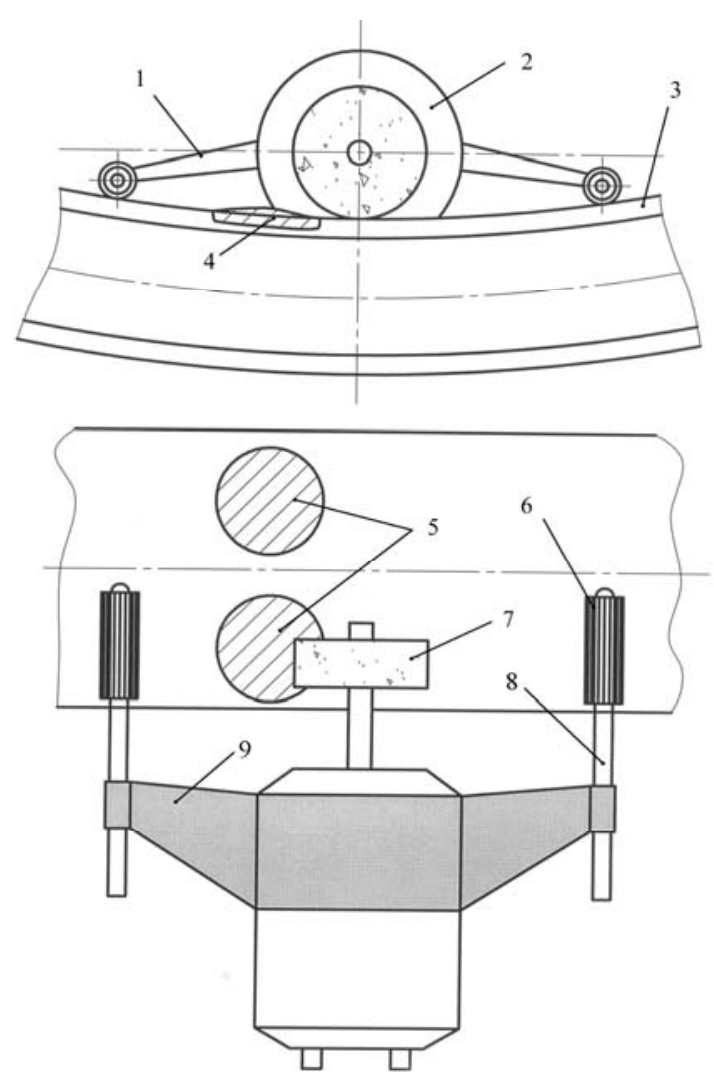

Fig. 3. The circuit of the device for polishing the monorails after gas-thermal evaporation:

1,9 are device for fastening the pneumatic tool;

2 is pneumatic or electrical tool;

3 is restored monorail;

4, 5 are evaporated coating;

6 is terminators of a distortion;

7 is the abrasive tool;

8 is guides

Thus, to advantages of the given devices it is possible to refer:

- an opportunity operatively to make repair;

- removal of the basic material is made with the minimal losses;

- the damage of a processed detail is reduced to a minimum;

- use most widespread on repair factories pneumoand electrotool.
To the disadvantages concern: individuality of calculation for concrete defect; presence of the certain amount of abrasive circles of the special form of various diameters; necessity periodically to control conformity of curvature of the device at polishing a monorail.

\section{Conclusions}

1. The developed devices make preparation of rails for restoration and polishing after evaporation, minimally damaging the basic material.

2. The devices allow operatively and with high accuracy to repair the damaged rails of mechanization of a wing.

3. Depth of the removal of metal it is necessary to calculate individually for each damage.

\section{References}

1. Исследования работоспособности защитных покрытий и упрочняющих технологий для восстановления рельсов механизации крыла самолета; Отчет о НИР за IV кв./ КИИГА; Науч. руководитель проф. А.Я. Алябьев, №133Х-92. - К., 1992. - 44 с.

2. Голего Н.Л., Алябьев А.Я., Шевеля В.В. Фреттингкоррозия металлов. - К.: Техніка, 1974. - 272 с.

3. Исследование триботехнических свойств плазменных оксидных покрытий применительно к условиям работы деталей узлов ГТД; Технич. отчет о НИР / КИИГА; Науч. руководитель Н.Л. Голего. - К., 1990. $143 \mathrm{c}$.

4. Технологические рекомендации по восстановлению рабочих лопаток турбин ГТД и рельсов механизации крыла самолетов; Отчет о НИР за I-II кв. / КИИГА; Науч. руководитель проф. А.Я. Алябьев, №482-В83. К., 1984. - С. 40-56.

5. Разработка метода выбора покрытий и справочных данных о триботехнических свойствах покрытий, применяемых с целью упрочнения и восстановления машин и механизмов, работающих в условиях фреттинга; Отчет о НИР за I-IV кв., КИИГА; Науч. руководитель проф. А.Я. Алябьев, №008-ГБ92. - К., 1993. - $78 \mathrm{c}$.

6. Газотермические покрытия из порошковых материалов: Справ. / Ю.С. Борисов, Ю.А. Харламов, С.Л. Сидоренко и др. - К.: Наук. думка, 1987. - 544 с.

The editors received the article on 6 July 2006. 